Research Article

\title{
An analysis of animal bite cases attending anti-rabies clinic attached to tertiary care centre, Bikaner, Rajasthan, India
}

\author{
Rekha Acharya, Renu Sethia, Gaurav Sharma, Rattiram Meena*
}

Department of Preventive Science Medicine, S. P. Medical College, Bikaner, Rajasthan, India

Received: 28 May 2016

Accepted: 15 June 2016

\author{
*Correspondence: \\ Dr. Rattiram Meena, \\ E-mail: drrattirammeena@gmail.com
}

Copyright: (c) the author(s), publisher and licensee Medip Academy. This is an open-access article distributed under the terms of the Creative Commons Attribution Non-Commercial License, which permits unrestricted non-commercial use, distribution, and reproduction in any medium, provided the original work is properly cited.

\begin{abstract}
Background: Rabies is a widespread, neglected and under reported zoonosis with an almost $100 \%$ case fatality rate in human untreated on time, and causes a significant social and economic burden. Objective: Analysis of animal bite cases attending Anti-rabies clinic attached to Prince Bijay Singh Memorial (PBM) hospital, Bikaner, Rajasthan. Methods: The study was conducted amongst patient who attended the Anti-rabies clinic attached to PBM hospital Bikaner for management of their Category II and III injuries caused by bites by various animals, during the 3 year period.

Results: Amongst 10916 victims who attended 8335 (76.36\%) were males and rest females (male: female ratio 3.2:1). $5796(53.10 \%)$ patients belonged to rural area and $5120(46.90 \%)$ were from urban area. The bite injuries involved different site. Bite of Lower limb accounted for the most 4980 cases $(45.62 \%)$ then were those of upper limb. Distribution of patients according to different age groups showed preponderance in the 0-10 year's age group $2768(25.35 \%)$ patients, $2266(20.07 \%)$ were in the 11-20 years age group. The most common biting animal was stray $\operatorname{dog}(76.33 \%)$. Month wise distribution showed highest incidence during January $11.11 \%$, and the least cases reported in the month of September $5.81 \%$.

Conclusions: India is amongst those countries reporting highest number of deaths due to rabies and also is amongst those countries where most people receive post exposure prophylaxis but true number is still lacking because of absence of well-organized surveillance system. Epidemiological studies like present study may help assess the true magnitude of problem.
\end{abstract}

Key Words: Rabies, Animal bite, Category II, Category III

\section{INTRODUCTION}

Rabies is a widespread, neglected and under reported zoonosis with an almost $100 \%$ case fatality rate in human untreated on time, and causes a significant social and economic burden. ${ }^{1}$ The disease is caused by a neurotropic virus belonging to the genus Lysa virus in the family Rhabdoviridae. The virus is transmitted by its introduction into wounds or cuts in skin or mucus membranes, most commonly by bites of rabid animals. ${ }^{2}$ An estimated 55,000 people die annually from rabies. ${ }^{3}$ The main biting animal is dog, mostly strays. ${ }^{4}$ Rabies is also found to occur following bites by rabid jackals, horse, cats, monkeys. ${ }^{5}$
The objective of this study was to study the epidemiological characteristic and anti- rabies practices in patient attending the tertiary care hospital Bikaner, Rajasthan, which will thereby help to create awareness amongst people and guide them to take appropriate preventive measure. This will then help to reduce the disease burden.

\section{METHODS}

The study was conducted amongst patient who attended the Anti-rabies clinic attached to Prince Bijay Singh Memorial (PBM) Hospital Bikaner, with Category II and III injuries caused by bite of animals, for management of 
animal bite. The study period was of three years, extending from $1^{\text {st }}$ April 2012 to $31^{\text {st }}$ March 2015. Data was collected from the record available at the clinic. Microsoft word and excel have been used to generate tables and graphs and also for analysis.

\section{RESULTS}

Amongst 10916 victims who attended the clinic during the duration with Category II and III injuries, majority were males $(76.36 \%$ ) and $23.64 \%$ were females (male: female ratio $3.2: 1)$.

Table 1: Socio demographic profile of study subjects.

\begin{tabular}{|ll|}
\hline Sex wise distribution & \\
\hline Sex & Frequency $\mathbf{n}=\mathbf{1 0 9 1 6}(\boldsymbol{\%})$ \\
\hline Male & $8335(76.36)$ \\
\hline Female & $2581(23.64)$ \\
\hline Geographical distribution & \\
\hline Rural/urban & Frequency $\mathbf{n}=\mathbf{1 0 9 1 6}(\boldsymbol{\%})$ \\
\hline Rural & $5796(53.10)$ \\
\hline Urban & $5120(46.90)$ \\
\hline Age wise distribution & \\
\hline Age groups (in years) & Frequency $\mathbf{n}=\mathbf{1 0 9 1 6}(\boldsymbol{\%})$ \\
\hline $0-10$ & $2768(25.35)$ \\
\hline $11-20$ & $2266(20.07)$ \\
\hline $21-30$ & $1669(15.28)$ \\
\hline $31-40$ & $1332(12.20)$ \\
\hline $41-50$ & $1361(12.46)$ \\
\hline $51-60$ & $980(8.97)$ \\
\hline$>61$ & $540(4.94)$ \\
\hline
\end{tabular}

Rural urban difference showed that $53.10 \%$ patients belonged to rural area and rest were from urban area.Distribution of patients according to different age groups showed most attacked $(25.35 \%)$ were those in the $0-10$ years age group, next $20.07 \%$ were in the 11-20 years age group, then $15.28 \%$ in the $21-30$ age group, $12.20 \%$ in the $31-40$ years age group, $12.46 \%$ in the 41 50 age group, $8.97 \%$ in the 51-60 age group and least $4.94 \%$ in the more than 61 year age group. Amongst 10916 patients 7270 (66.59\%) belonged to Category II and $5790(33.40 \%)$ to Category III. The bite injuries involved different site of which lower limb accounted for the most (45.62\%), then upper limb $(29.95 \%)$. Head and neck accounted for $13.83 \%$ cases and the site least involved was trunk, accounting for $10.58 \%$ injuries.

Table 2: Site of bites wise distribution.

\begin{tabular}{|ll|}
\hline Site & Frequency $\mathbf{n}=\mathbf{1 0 9 1 6}(\%)$ \\
\hline Upper limb & $3270(29.95)$ \\
\hline Lower limb & $4980(45.62)$ \\
\hline Trunk & $1156(10.58)$ \\
\hline Head and neck & $1510(13.83)$ \\
\hline
\end{tabular}

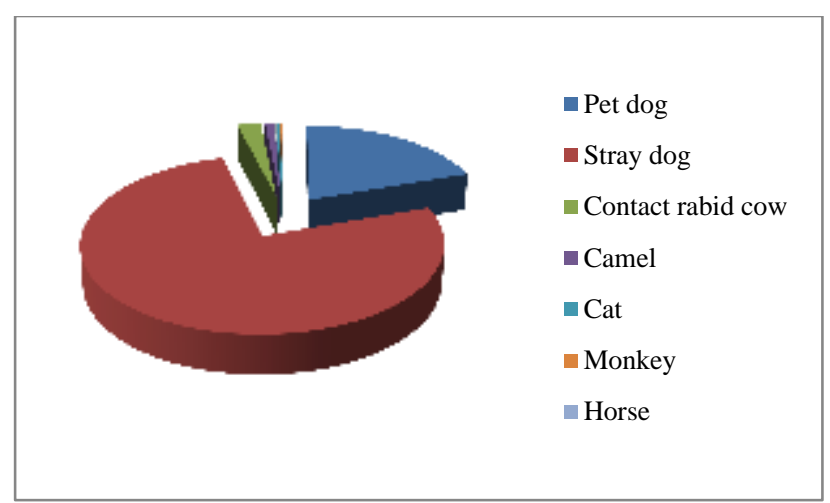

Figure 1: Animal wise distribution.

In this study the most common biting animal was stray $\operatorname{dog} 76.33 \%$ followed by pet dog which were responsible for $19.54 \%$ bite. Contact with rabid cow accounted for $2.38 \%$ of cases. Few cases of bites from other animals also reported - camel $0.96 \%$, cat $0.40 \%$, monkey $0.15 \%$, and horse $0.13 \%$.

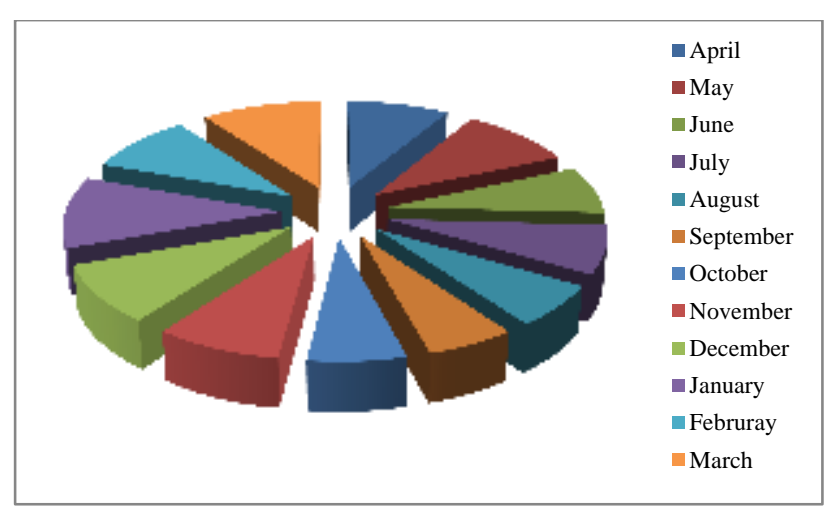

Figure 2: Month wise distribution.

During the three year period the incidence of cases in different months were follows- January $11.11 \%$, February 9.25\%, March 10.23\%, April 8.69\%, May 9.73\%, June $7.48 \%$, July $7.48 \%$, August $6.47 \%$, September $5.81 \%$, October $6.39 \%$, November $8.25 \%$ and December $9.06 \%$.

\section{DISCUSSION}

In this study demographical profile showed a male predominance $(76.36 \%)$ with a male: female ratio $3.2: 1$, this is probably because rabies is an exposure related disease and as males move out of their house more than females, mainly because of occupational purpose, males are affected more than females. This observation corroborates with the observation made by many other authors in their respective studies. ${ }^{4-16}$

The study also shows that the victims of the bite mainly belonged to rural area this may be because they are mainly involved in outdoor activities and hence more exposed to bite by various animals. Also in rural areas there are more animals. This observation is in concordance with various other studies. ${ }^{4,16}$ 
Amongst the different age group children below 10 year have been found maximally affected, followed by children in 11-20 years group. Children are the principal victims because their inherent fondness to animal, because of their tendency to provoke animals and also because they are less likely to defend themselves against the attack by rabid animals. This observation corroborates well with other studies. ${ }^{17-19}$

The site wise distribution showed lower limb to be the most commonly affected site. This is not unusual as it is the most accessible and this observation corroborates with study by Singh J, Jain DC, Bhatia R, Ichhpujani RL, Harit AK, Panda RC, et al. ${ }^{13}$

In our study $66.59 \%$ patients belonged to Category II and $33.40 \%$ belonged to Category III. The distribution on the type of biting animal showed that the most common animal involved was dog. Stray dog were responsible for the majority of bites $(76.33 \%)$ and pet dogs accounted for around $20 \%$ of bites.

Bikaner has very high population of stray dogs. Same conclusion has been drawn in other studies also. ${ }^{7}$ The next main cause was by contact with rabid cow which accounted for $2.38 \%$ of cases. Bikaner has a lot of dairies which is responsible for high number of cows and thereby people having more chances of contact with rabid cows.

This study showed increased number of cases in winter and summer. The study made by Behera TR, Satapathy DM, Tripathy RM, Sahu A in Berhampur, Orrisa also shows a rise number of cases in summer and winter months. ${ }^{10}$ The study made by Hanspal JS, Bhandari D, Nagar $\mathrm{S}$ also show rise in number in winter month. ${ }^{12}$

\section{CONCLUSION}

The observations made in this study have corroborated well with other studies. Because rabies is not a modifiable disease in India and there is no organised surveillance system, the actual number of cases and deaths might be higher. ${ }^{20}$ Epidemiological studies like present study may help assess the true magnitude of problem.

Stringent measure including patient education, early initiation of post exposure prophylaxis in the form of modern tissue culture vaccine, and administration of human rabies immunoglobulin, antimicrobial therapy for high risk wounds and control of population of stray dogs needs to be undertaken to reduce of the social and economical burden of disease.

Funding: No funding sources Conflict of interest: None declared

Ethical approval: The study was approved by the Institutional Ethics Committee

\section{REFERENCES}

1. Recommendation of the Organisation for Animal Health. Global Conference on Rabies Control: Towards Sustainable Prevention at the Source.7-9 September, 2011. Available at: http://www.oie.int/fileadmin/Home/eng/Conference s_Events/docs/pdf/recommendations/A_Recommen dation_Global\%20Rabies\%20Conference\%20Seoul _final.pdf.

2. Krebs JW, Wilson ML, Childs JE. Rabies: epidemiology, prevention, and future research. Journal of Mammalogy.1995;76(3):681-94.

3. Sudarshan MK, Mahendra BJ, Madhusudana SN, Ashwoath Narayana DH, Rahman A, Rao NS et al. An epidemiological study of animal bites in India: results of a WHO sponsored national multi-centric rabies survey. J Commun Dis. 2006;38(1):32-9.

4. Shetty RA, Chaturvedi S, Singh Z. Profile of animal bite cases in Pune. J Commun Dis. 2005;37(1):66-72.

5. Salve H, Kumar S, Sa R, Rai SK, Kant S, Pandav CS. Feasibility of sustainable provision of intradermal post exposure prophylaxis against rabies at primary care level-evidence from rural Haryana. BMC Health Serv Res. 2014;14:278.

6. Below poverty line (India). http.//en.wikepedia.org.

7. Sudarshan MK, Mahendra BJ, Narayan DH. A community survey of dog bites, anti-rabies treatment, rabies and dog population management in Bangalore city. J Commun Dis. 2001;33(4):245-51.

8. Shah V, Bala DV, Thakker J, Dalal A, Shah U, Chauhan $\mathrm{S}$ et al. Epidemiological determinants of animal bite cases attending the anti- rabies clinic at V S General Hospital, Ahmedabad. Indian J Community Med. 2012;3(1):66-8.

9. Ichhpujani RL, Mala C, Veena $M$, Singh J, Bhardwaj M, Bhattacharya D et al. Epidemiology of animal bites and rabies cases in In dia. A multicentric study. $\mathrm{J}$ Commun Dis. 2008;40(1):27-36.

10. Behera TR, Satapathy DM, Tripathy RM, Sahu A. Profile of animal bite cases attending the ARC of MKCG Medical College. APCRI Journal. 2008; IX(2):20-5.

11. Goel S, Gupta H, Mazta SR. Epidemiological profile of Bite Cases Admitted at a 50 bedded Community Health Centre of Himachal Pradesh, India. The Internet Journal of Health. 2008:7.

12. Hanspal JS, Bhandari D, Nagar S. A review of attendance trend of animal bite cases inthe anti rabies clinic of GGS Hospital, Jamnagar (Gujarat). APCRI Journal. 2007;8:16-8.

13. Singh J, Jain DC, Bhatia R, Ichhpujani RL, Harit AK, Panda RC, et al. Epidemiological characteristics of rabies in Delhi and surrounding areas, 1998. Indian Pediatrics. 2001;38:1354-60.

14. Haque MS, Yeasmin T, Islam MM. Epidemiological characteristics of human rabies at Infectious Disease 
Hospital, Dhaka. Bangladesh J Child Health. 2011;35:102-7.

15. Buzgan T, Irmak H, Yılmaz GR, Torunoğlu MA, Safran A. Epidemiology of human rabies in Turkey, 1992-2007. Turk J Med Sci. 2009;39:591-7.

16. Menezes R. Rabies in India. CMAJ. 2008;178:5646.

17. Weiss HB, Friedman DI, Coben JH. Incidence of dog bite injuries treated in emergency departments. JAMA. 1998;279(1):51-3.

18. Monory A, Behar P, Nagy M. Head and neck dog bites in children. Otolaryngol Head Neck Surg. 2009;140:354-7.

19. Masthi NRR, Narayana DHA, Kulkarni P, Gangaboraiah, Belludi A. Epidemiology and prevention of animal bite and human rabies in a rural community-One health experiment. Asian Pac J Trop Dis. 2014;4:S486-S490.

20. Bata SI, Dzikwi AA, Ayika DG. Retrospective study of dog bite cases reported to ECWA veterinary clinic, Bukuru, PlateauState, Nigeria. Sci World J. 2011;6:17-9.

Cite this article as: Acharya R, Sethia R, Sharma G, Meena P. An analysis of animal bite cases attending anti-rabies clinic attached to tertiary care centre, Bikaner, Rajasthan, India. Int J Community Med Public Health 2016;3:1945-8. 